\title{
Analysis of direct punch velocity in professional defence
}

Dora Lapkova and Milan Adamek

Citation: AIP Conference Proceedings 1738, 120016 (2016); doi: 10.1063/1.4951899

View online: http://dx.doi.org/10.1063/1.4951899

View Table of Contents: http://aip.scitation.org/toc/apc/1738/1

Published by the American Institute of Physics 


\title{
Analysis of Direct Punch Velocity in Professional Defence
}

\author{
Dora Lapkova and Milan Adamek \\ Tomas Bata University in Zlin, Faculty of Applied Informatics \\ nám. T.G. Masaryka 5555, 76001 Zlín, Czech Republic
}

\begin{abstract}
This paper is focused on analysis of a direct punch. Nowadays, professional defence is basic part of effective protection of people and property. There are many striking techniques and the goal of this research was to analyze the direct punch. The analysis is aimed to measure the velocity with help of high speed camera Olympus i-Speed 2 and then find the dependences of this velocity on input parameters. For data analysis two pieces of software were used - i-Speed Control Software and MINITAB. 111 participants took part in this experiment. The results are presented in this paper especially dependence of mean velocity on time and difference in velocity between genders.
\end{abstract}

Keywords: direct punch; professional defence; camera; velocity; differences

PACS: 06.30.Gv, 87.85.gj, 07.68.+m

\section{INTRODUCTION}

Professional defence is a field which is primary focused on the legal protection of person interests. It covers various areas - theory and practice of defence, attack and prevention, scientific disciplines such as tactics (e.g. skill in the counter attack), strategy (precautionary action) and operation (behaviour after a conflict situation). Moreover, it includes the knowledge of somatology and the chosen parts of crisis management, especially the phase of the conflict and solutions to conflict situations [1].

The striking techniques are one of the basic elements of the majority of combat sports [2], martial arts [3] or combat systems [4]. In these techniques the striking energy [1] is transferred through arms, legs or head. In this paper the direct punch velocity is closely analyzed. The direct punch is delivered by the arm following a direct line. The hitting area is a closed fist [5]. The aim is to stop the attacker and increase distance between the defender and an attacker. In the following experiment the punch was delivered by the back hand (see Fig. 1) [6].

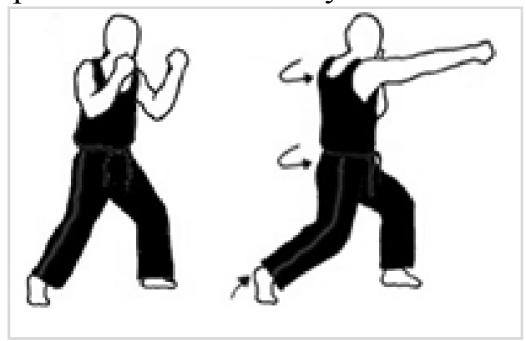

FIGURE 1. Direct punch [6]

\section{MEASURING STATION}

A high-speed camera Olympus i-Speed 2 [7] was used for measuring of velocity. This camera has CMOS $800 \times 600$ sensor, full resolution recordings to $1000 \mathrm{fps}$ (fps = frames per second) and $33000 \mathrm{fps}$ maximum recording speed. We used recording speed 1000 fps $[8,9,10]$. The measuring station consists of a punching bag and a construction of its suspension. Paper with two perpendicular lines was stuck on the right of the punching bag. Horizontal line was for leading the hand during movement. The aim of the vertical line was to determine the beginning of data analysis. The result was that the all direct punches were measured in the same distance from punching bag. This distance was $60 \mathrm{~mm}$. The end of the measuring was at the moment when the movement of the hand was stopped in axis " $\mathrm{x}$ " - the deformation of punching bag was at the maximum $[6,11]$. 


\section{EXPERIMENT}

The total of 111 participants took part in the experiment; 88 men and 23 women. Based on the previous training and experience the participants were divided into following three groups:

- Untrained - These people have never done any combat sport, martial art or combat system. Noted further as UTM (for men) and UTW (for women).

- Mid-trained - These people have the theoretical knowledge of striking techniques and they have attended the Special physical training course for at least six months. The course is focused on self-defence and professional defence at Tomas Bata University in Zlin. Noted further as MTM (for men) and MTW (for women).

- Self-trained - These people do some combat sports, martial arts or combat system for less than two years. Noted further as STM (for men).

- Trained - These people do some combat sports, martial arts or a combat system for longer than two years. Noted further as TM (for men) and TW (for women).

During the experiment each person made one strike (Except one man from training group. He did two strikes.). During the measurement the target was positioned in such manner that the center of the punching bag was in line with the striking person's shoulder. Reflective markers with diameter $10 \mathrm{~mm}$ have been stuck on the hand of each person.

\section{RESULTS}

For data analysis we used i-Speed Control Software. It is used for image analysis and for work with images modification of contrast, brightness etc. On the basis of sequential labelling of markers on hand the software it is able to calculate the velocity of the hand. The rate of images (1000 fps) and the distance of markers between two images are known [6].

For velocity analysis we used software MINITAB. It was possible to find out dependence of the mean velocity on time, dependence of the maximum velocity on body's height and mass, dependence of the maximum velocity on training level and also on gender.

Figures 2 and 3 show dependences of the velocity on time for men and women. There are clear differences among signals due to the training level and the gender.

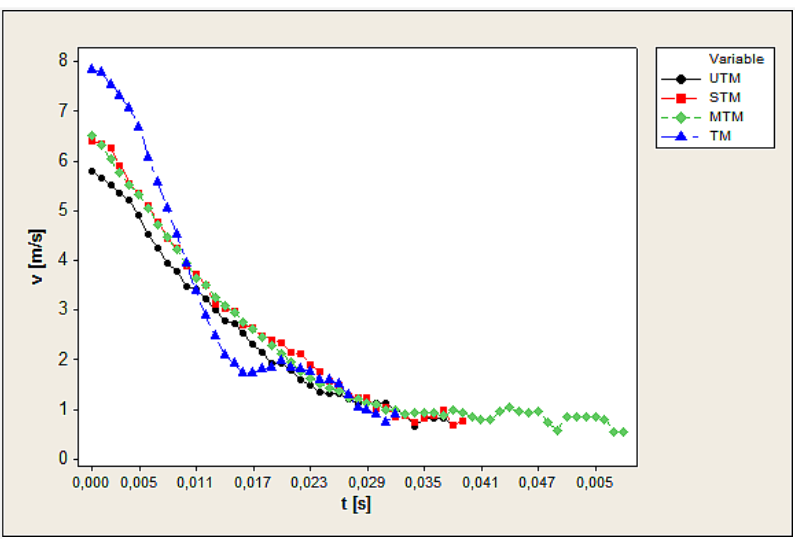

FIGURE 2. Dependence of mean velocity on time for men

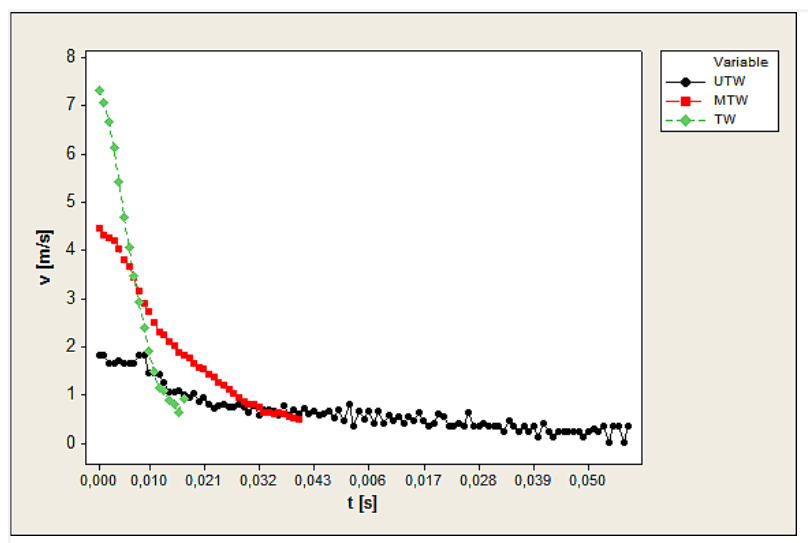

FIGURE 3. Dependence of mean velocity on time for women

Clearly differences among groups according to training level result from previous figures. There are not only differences in maximum velocity, but also in time of direct punch. Very interesting is fall of velocity. There is very sharp fall in group of training men and women. Other groups have less sharp fall.

The aim was to find out a simple statistical classifier which would helps us to classify people on basis of their training level. Possibilities are the maximum of velocity and its standard deviation (Table 1). 
TABLE 1. Results overview

\begin{tabular}{cccccccc}
\hline & Mean & StDev & CoefVar & Min & Median & Max & Number of samples \\
\hline UTM & 3,06 & 1,6 & 52,61 & 0,77 & 2,81 & 5,86 & 10 \\
STM & 3,16 & 1,76 & 55,83 & 0,7 & 2,76 & 6,44 & 7 \\
MTM & 3,05 & 1,82 & 60,35 & 0,57 & 2,76 & 6,52 & 32 \\
TM & 4,55 & 2,43 & 54,25 & 1,15 & 4,46 & 7,87 & 39 \\
UTW & 0,67 & 0,44 & 66,66 & 0 & 0,58 & 1,82 & 1 \\
MTW & 2,14 & 1,25 & 58,25 & 0,47 & 1,82 & 4,46 & 16 \\
TW & 3,65 & 2,37 & 64,29 & 0,69 & 3,35 & 7,34 & 6 \\
\hline
\end{tabular}

Very interesting is maximum velocity. In the group of trained men and women there are not expressive differences between themselves, but there are big differences between lower group mid-trained men and women. We can say that bigger differences among groups according to training level are in women.

Very important part of experiment was to find out if it is possible to determine dependence of maximum velocity on body's height and mass. This is so important because it is expected that tall men with bigger weight would have stronger punch than small and thin men.

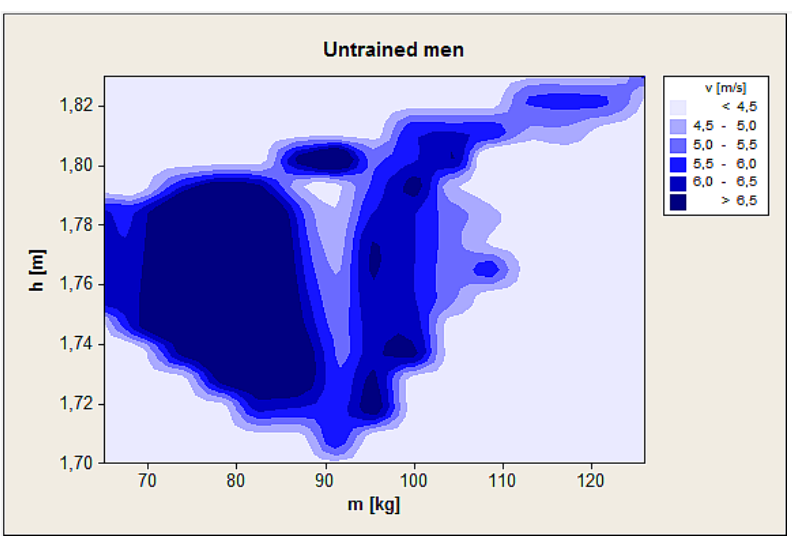

FIGURE 4. Dependence of maximum velocity on body's height and mass for untrained men

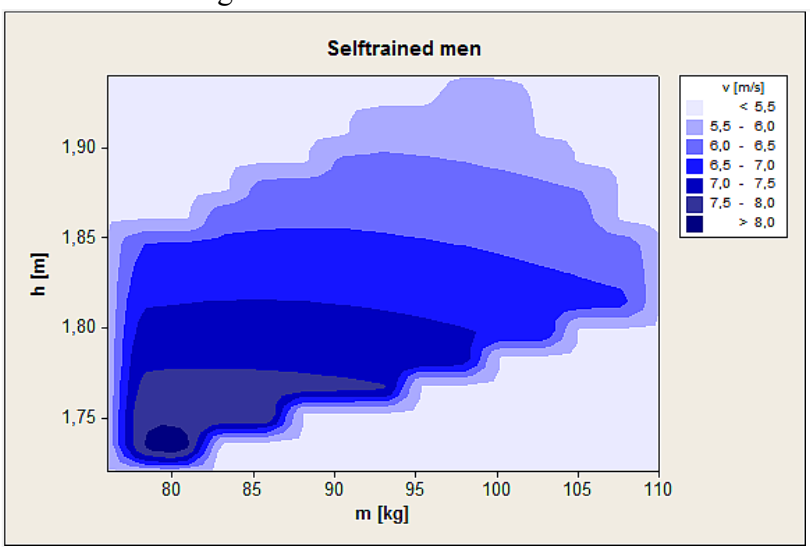

FIGURE 6. Dependence of maximum velocity on body's height and mass for self trained men

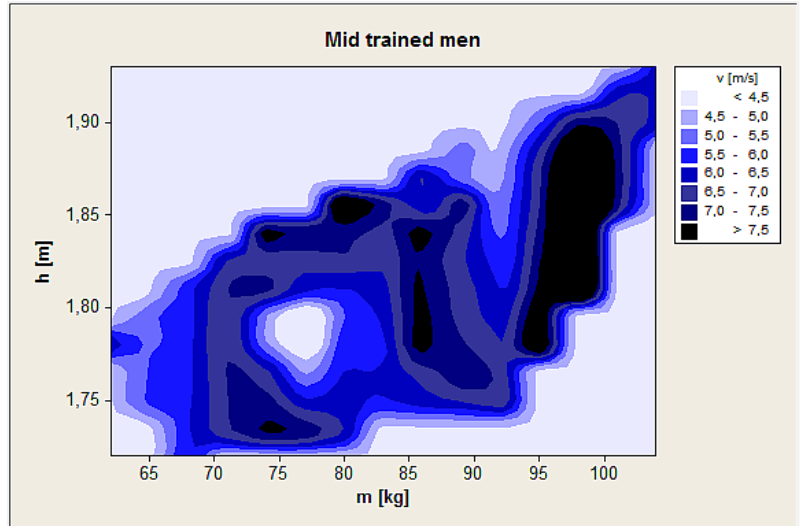

FIGURE 5. Dependence of maximum velocity on body's height and mass for mid-trained men

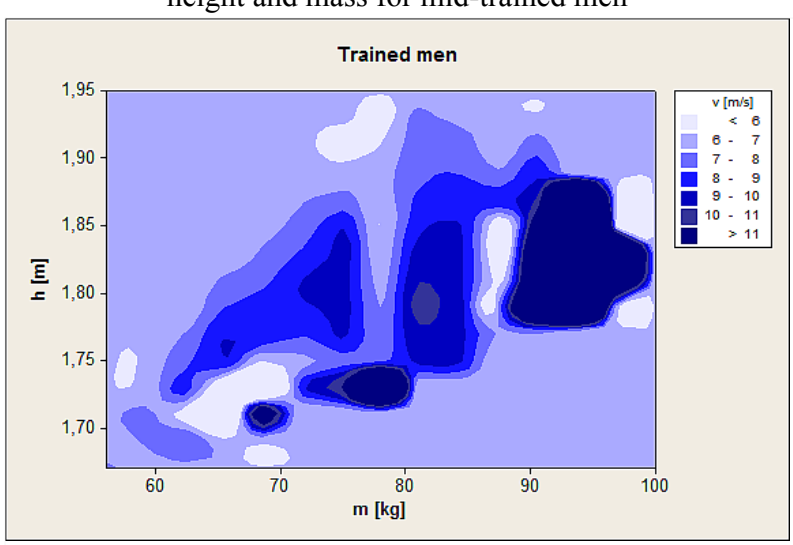

FIGURE 7. Dependence of maximum velocity on body's height and mass for trained men 


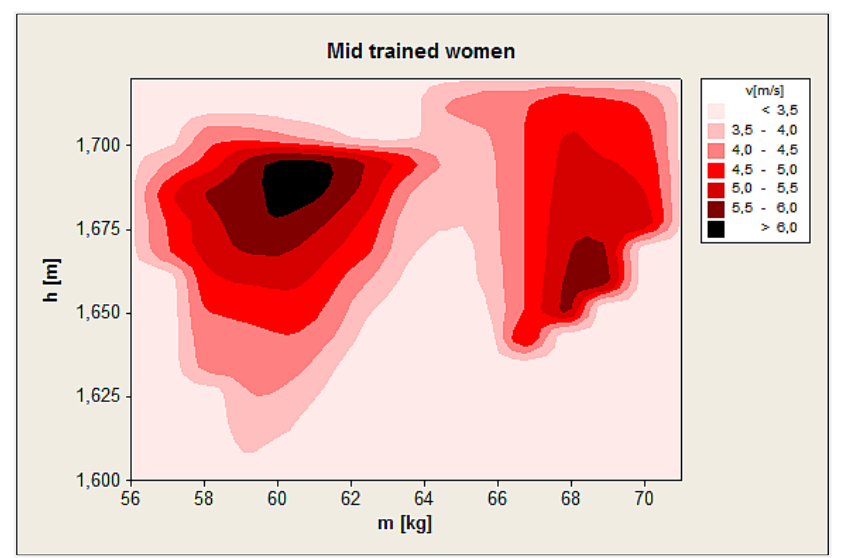

FIGURE 8. Dependence of maximum velocity on body's height and mass for mid-trained women

It can be seen (Fig.4-8) there is no evident dependence of the maximum velocity on body's height and mass. Only in category of self-trained men there is a trend of bigger maximum velocity with lower height and also with lower mass. In category of mid-trained men there is a trend of bigger maximum velocity with bigger mass.

\section{CONCLUSION}

The experiment was focused on analysis of direct punch with a view to velocity. The high-speed camera Olympus iSpeed 2 and software i-Speed Control Software and MINITAB were used. The results are measuring of velocity in time and the maximum velocity. The aim was to find dependences of velocity on input parameters such as body's height and mass, gender and training level. It can be stated that there is a big difference between genders on the same training level. Dependences on body's height and mass are not evidential.

\section{REFERENCES}

1. D. Lapkova, M. Pospisilik, M. Adamek and Z. Malanik Z, The utilisation of an impulse of force in self-defence. In: $X X$ IMEKO World Congress: Metrology for Green Growth.Busan, Republic of Korea, 2012, ISBN: 978-89-950000-5-2

2. G. Blower, Boxing: Training, Skills and Techniques. Crowood, 2007

3. H. Chiu and T. Shiang, A new approach to evaluate karate punch techniques. [online]. [cit. 2012-06-27]. Available: http://w4.ub.uni-konstanz.de/cpa/article/viewFile/4052/3751

4. D. Levine and J. Whitman, Complete Krav Maga. 2007

5. Z. Reguli, Inovace SEBS a ASEBS: Inovace bakalářského studijného oboru Speciální edukace bezpečnostních složek a navazujícího magisterského studijního oboru Aplikovaná sportovní edukace bezpečnostních složek. Biomechanika úpolových sportů a bojových umění [online]. 2011, Available: http://www.fsps.muni.cz/inovace-SEBSASEBS/elearning/biomechanika/biomechanika-upolovych-sportu

6. D. Lapkova and M. Adamek, Analysis of Direct Punch with a View to Velocity. In Proceedings of the 2014 International conference on Applied Mathematics, Computational Science and Engineering. Craiova : Europment, 2014, s. 0-9. ISSN 2227-4588. ISBN 978-1-61804-246-0.

7. J. Pešek, High speed digital imaging system I-Speed 2 and its application. Brno, 2008. Bachelor's thesis. Brno University of Technology. Advisor doc. Dr. Ing. Vladimír Pata

8. M. Baroň, Measurement and evaluation of high-speed processes using high-speed camera system Olympus i-SPEED 2. Zlín, 2010. Thesis. Tomas Bata University in Zlin. Advisor doc. Dr. Ing. Vladimír Pata

9. P. Kolomaznik, Methodology of fast and stochastic mechanical process research. Brno, 2008. Thesis. Brno University of Technology. Advisor doc. Dr. Ing. Vladimir Pata

10. C. Gianino, Physics of Karate: Kinematics analysis of karate techniques by a digital movie camera. Latin-American Journal of Physics Education, 2010, 4.1: 5

11. D. Lapkova, Z. Malanik and M, Use of the high-speed camera in self-defence. In: Annals of DAAAM for 2011 \& Proceedings of the 22nd International DAAAM Symposium "Intelligent Manufacturing \& Automation: Power of Knowledge and Creativity". Vienna: DAAAM International Vienna, 2011, s. 1531-1532. ISBN 978-3-901509-83-4.

12. R. P. Bolander, O. P. Neto and C. A. Bir, The effects of height and distance on the force production and acceleration in martial arts strikes. Journal of Sports Science and Medicine [online]. 2009, roč. 8, s. 47-52 [cit. 2012-06-27]. Available: http://www.jssm.org/combat/3/9/v8combat3-9.pdf

13. D. Lapkova, M. Pluhacek and M. Adamek, Computer Aided Analysis of Direct Punch Force Using the Tensometric Sensor. In: Modern Trends and Techniques in Computer Science: 3rd Computer Science On-line Conference 2014 (CSOC 2014 ). Springer, 2014, s. 507-514. ISBN 978-3-319-06739-1.ISSN 2194-5357 